\title{
References
}

1. Dornbusch K, Miller GH, Hare RS, Shaw KJ, and the ESGAR Study Group. Resistance to aminoglycoside antibiotics in gram-negative bacilli and staphylococci isolated from blood. Report from a European collaborative study. I Antimicrob Chemother 1990; 26, 131-144.

2. Dornbusch K, and the European Study Group on Antibiotic Resistance. Resistance to $\beta$-lactam antibiotics and ciprofloxacin in gram-negative bacilli and staphylococci isolated from blood: a European collaborative study. If Antimicrob Chemother 1990; 26, $269-278$.

3. The Greek Society for Microbiology. Antibiotic resistance among gram-negative bacilli in 19 Greek hospitals. F Hosp Infect 1989; 14, 177-181.

4. Sanford JP. Lower respiratory tract infections. In Hospital Infections. Bennet JV Brachman PS, Eds. Boston: Little Brown, 1986.

5. National Committee for Clinical Laboratory Standards. Performance standards for antimicrobial disc susceptibility tests. Publication NoM2A2. Villanova, Pa: NCCLS, 1982.

6. McGowan JE. Antimicrobial resistance in hospital organisms and its relation to antibiotic use. Rev Infect Dis 1983; 5, 1033-1048.

7. McGowan JE. Is antimicrobial resistance in hospital microorganisms related to antibiotic use? Bull NY Acad Med 1987; 63, 253-268.

8. Brown EH, Spencer RC, Brown JMC. The emergence of bacterial resistance in hospitals - a need for continuous surveillance. F Hosp Infect 1990; 15 suppl. A, 35-39.

9. Tzelepi E, Tzouvelekis LS, Vatopoulos AC, Mentis AF, Tsakris A, Legakis NJ. High prevalence of stably derepressed class-I $\beta$-lactamase expression in multiresistant clinical isolates of Enterobacter cloacae from Greek hospitals. F Med Microb 1992; 37, 91-95.

10. Vatopoulos AC, Philipon A, Tzouvelekis LS, Komninou Z, Legakis NJ. Prevalence of a transferable SHV-5 type $\beta$-lactamase in clinical isolates of Klebsiella pneumoniae and Escherichia coli in Greece. F Antimicrob Chemother 1990; 26, 635-648.

11. Vatopoulos AC, Tsakris A, Tzouvelekis LS, et al. Diversity of aminoglycoside resistance in Enterobacter cloacae in Greece. Eur $\mathcal{Y}$ Clin Microb Infect Dis 1992; 11, 131-138.

Sir,

\section{Mupirocin susceptibility in vitro and nasal eradication of epidemic methicillin-resistant Staphylococcus aureus}

In order to investigate the therapeutic efficacy of mupirocin we studied its activity in an outbreak of nosocomial infection due to methicillin-resistant Staphylococcus aureus (MRSA) in our hospital.

Nasal carriers of MRSA were treated with calcium mupirocin nasal ointment 2\% 8-hourly for seven days. From April 1990 until June 1992, MRSA isolates (nasal and/or cutaneous and/or pharyngeal) were obtained from 694 patients. Sixty-eight patients were colonized by MRSA with a MIC $>4 \mathrm{mg} \mathrm{l}^{-1}$ of mupirocin. Of these, $75 \%$ had been colonized previously by susceptible strains. The MICs of these low-level mupirocin resistant strains ranged from 8 to $16 \mathrm{mg}^{-1}$, and those of susceptible strains from 0.06 to $0.25 \mathrm{mg} \mathrm{l}^{-1}$. 
The mupirocin-resistant isolates were found in the intensive care unit and in three of the four hospital wards where MRSA carriers were isolated.

We assessed the efficacy of mupirocin nasal treatment in bacterial eradication from this site, in patients colonized at multiple sites. Eradication was defined as negative nasal swabs taken at weekly intervals for three weeks after treatment. Table I compares nasal eradication in patients colonized in the nose alone with those colonized at multiple sites by strains with low-level mupirocin resistance.

Although the difference in failure rates was not statistically significant, probably due to the small sample size, these data seem to indicate that colonization at multiple sites is clinically more important in failure of topical nasal treatment than low-level mupirocin resistance.

M. C. Gaspar

P. Sánchez

P. Uribe

R. Coello

P. Arroyo

F. Cruzet
Preventative Medicine Dept., University Hospital San Carlos, Martin Lagos s/n, Madrid 28040, Spain.

Table I. Response to mupirocin by resistant $M R S A$ strains: comparison of response between patients colonized in nose alone with those colonized at multiple sites.

\begin{tabular}{lcc}
\hline & Nose alone & Multiple sites \\
\hline Eradication & $12(92 \%)$ & $\begin{array}{c}14(61 \%) \\
\text { Persistence }\end{array}$ \\
\hline Total & 1 & 23 \\
\hline
\end{tabular}

Fisher's exact test $P=0 \cdot 059$.

\section{References}

1. Sutherland RN, Boon RJ, Griffin KE, Masters PJ, Slocombe BC, White AR. Antibacterial activity of mupirocin (pseudomonic acid), a new antibiotic for topical use. Antimicrob Agents Chemother 1985; 27: 495-498. 